\title{
POTENSI TUNGGAK Acacia Crassicarpa DAN EKONOMI PEMANFAATAN SEBAGAI BAHAN BAKU ARANG
}

\author{
(The Potency of Stump of Acacia crassicarpa and Economic \\ Utilization as the Raw Materials Charcoal Resources) \\ Yanto Rochmayanto ${ }^{1}$ \\ ${ }^{1)}$ Balai Penelitian Hutan Penghasil Serat \\ Jalan Raya Bangkinang-Kuok Km 9, Bangkinang, Riau (28463) \\ Tlp (0762) 7000122, Fax (0762) 7000122, e-mail : yrochmayanto@yahoo.co.id
}

Naskah masuk : 25 Maret 2011; Naskah diterima : 22 Februari 2012

\begin{abstract}
Wood properties of Acacia crassicarpa stump are suitable for the charcoal raw material. There are many sources of stump, therefore it is important to know how the phisical and economical potency. The objectives of this research are to know: (1) potency of A. crassicarpa stump at harvesting area of pulpwood industrial platation forest, and (2) feasibility of charcoal business made of A. crassicarpa stump. Potency of the stumps are predicted by square plot $23.36 \mathrm{~m} \times 23.36 \mathrm{~m}$, using randomized systematic sampling method. Business feasibility was analyzed by means of financial analysis method for investment on home industry scenarios. The result of this research showed that total potency of stump of A. crassicarpa on peatland are 15.8 ton/ha or 222 staple meter/ha, and merchantable stump are 3 ton/ha $(18.8 \%$ from total weight potency) or 39 staple meter/ha (17.6\% from total volume potency). The business is not feasible for investment scenario, but for home industry scenario with subsidize or as an alternative/additional employment is feasible with NPV of Rp 1,435,000,- and Rp 2,050,000,- per month, BCR 1.5 and 2.0 were for drum and groundhole combustion method. IRR for both are $14.52 \%$.
\end{abstract}

\section{Keywords: Charcoal, feasibility study, raw material, stump of Acacia crassicarpa, potency}

\begin{abstract}
ABSTRAK
Tunggak Acacia crassicarpa memiliki sifat dasar yang sesuai untuk bahan baku arang. Sumber tunggaknya berlimpah, tetapi belum diketahui potensi fisik maupun ekonominya. Penelitian ini bertujuan mengetahui : (1) potensi tunggak A. crassicarpa yang dapat dimanfaatkan pada areal tebang HTI pulp, dan (2) tingkat kelayakan pengusahaan arang dari tunggak $A$. crasicarapa. Potensi tunggak dihitung dengan plot berukuran 23,36 x 23,36 m yang ditempatkan secara sistematik dengan awal acak. Kelayakan usaha dianalisis menggunakan metode analisis finansial pada skenario investasi dan skala rumah tangga. Hasil penelitian menunjukkan bahwa total potensi tunggak kayu A. crassicarpa di HTI lahan gambut adalah 15,8 ton/ha atau $222 \mathrm{sm} / \mathrm{ha}$, dan potensi tunggak termanfaatkan 3 ton/ha $(18,8 \%$ dari bobot total) atau $39 \mathrm{sm} / \mathrm{ha}$ (17,6\% dari volume total). Pengusahaan arang tunggak belum layak sebagai sebuah investasi, sedangkan sebagai usaha rumah tangga melalui subsidi atau sebagai lapangan kerja alternatif/tambahan adalah layak dengan NPV sebesar Rp 1.435.000,- dan Rp 2.050.000,- per bulan, BCR 1,5 dan 2,0 masing-masing untuk metode drum dan lubang tanah. IRR pada kedua metode adalah $14,52 \%$.
\end{abstract}

Kata kunci : Arang, bahan baku, kelayakan usaha, tunggak Acacia crassicarpa, potensi 


\section{PENDAHULUAN}

Luas Hutan Tanaman Industri (HTI) sampai tahun 2005 sudah mencapai 2,5 juta ha (Rimbawanto, 2007) dan pada tahun 2006 luasnya bertambah menjadi 3,65 juta ha (Departemen Kehutanan, 2007). Hampir separuh diantaranya adalah HTI pulp dengan jumlah luas sampai dengan tahun 2006 adalah 1.875.804,80 ha (Departemen Kehutanan, 2008).

Gambaran luasan tersebut memberikan indikasi bahwa banyaknya sisa tebangan yang belum dapat dimanfaatkan sebagai bahan baku kayu serpih maupun energi. Potensi tunggak di areal tebangan sangat berlimpah dan keberadaannya jika dibiarkan dapat menjadi sarang jamur perusak akar tanaman muda pada rotasi tanam berikutnya sehingga dapat mengakibatkan kematian pada tanaman tersebut (Pusat Litbang Hasil Hutan, 2009). Berlimpahnya tunggak tidak dibarengi oleh pemanfaatannya, karena sampai saat ini belum ada pihak yang melakukan upaya pemanfaatannya. Hal tersebut disebabkan belum diketahuinya potensi kegunaannya. Salah satu upaya pemanfaatan tunggak yang dapat dilakukan adalah dengan pembuatan tunggak sebagai kayu energi berupa arang.

Sifat dasar tunggak $A$. crassicarpa telah dikaji secara laboratoris oleh Rochmayanto et al. (2009). Berat jenisnya diketahui sebesar 0,71 $\mathrm{gr} / \mathrm{cm}^{3}$, arah serat berpilin, kelas keawetan III-IV, dan nilai kalor $4.342 \mathrm{kal} / \mathrm{gr}$. Sifat-sifat tersebut menggambarkan kesesuaiannya terhadap kebutuhan sifat kayu yang dikehendaki sebagai bahan baku arang. Persyaratan bahan baku arang antara lain berat jenis tinggi, jenis kayunya keras dan kuat (Setiawan, 2009),serta memiliki nilai kalor yang relatif tinggi (Pusat Litbang Hasil Hutan, 2009).

Kebutuhan arang sampai saat ini cukup banyak, sementara bahan baku kayu makin berkurang. Sebagai contoh, kasus permintaan arang tempurung kelapa di internal di Sumatera Utara 1.800 ton/tahun, dan peluang permintaannya akan lebih besar jika dipasarkan ke berbagai industri arang aktif di Jakarta serta permintaan rumah tangga diperhitungkan. Permintaan luar negeri dapat dicermati dari volume ekspor arang tempurung kelapa sebesar $26.360 .600 \mathrm{~kg}$ pada tahun 2000 (Bank Indonesia, 2009).

Lebih lanjut Rostiwati, Heryati dan Bustomi (2006) mengemukakan bahwa pemakaian arang di Indonesia masih terbatas untuk bahan bakar.
Kebutuhan energi dari arang untuk daerah perkotaan adalah 191.000 ton dan di pedesaan 251.000 ton. Selain untuk kebutuhan domestik arang kayu juga memiliki peluang sebagai komoditas ekspor.

Berkaitan dengan peluang pemanfaatan tunggak kayu $A$. crassisarpa sebagai bahan baku arang, sebelum dilakukan transfer teknologi dan informasi kepada masyarakat pengguna, penting diketahui seberapa besar potensi tunggak per hektar yang dapat dimanfaatkan (merchantable stump) dari areal HTI $A$. crassicarpa. Jika akan dikembangkan, pertanyaan berikutnya adalah bagaimana analisis biaya dan kelayakan usaha untuk pembuatan arang dari $A$. crassicarpa?

Penelitian ini bertujuan untuk memperoleh informasi potensi tunggak di HTI $A$. crassicarpa sebagai sumber bahan baku pembuatan arang dan kelayakan usaha pembuatan arang dari tunggak A. crasicarapa.

\section{METODOLOGI}

\section{A. Lokasi Penelitian}

Lokasi penelitian berada di Distrik Berbari PT. Arara Abadi. Secara administratif lokasi penelitian terletak di Desa Berbari, Kecamatan Pusaka, Kabupaten Siak, Provinsi Riau. Lokasi penelitian termasuk pada areal tebangan RKT 2010.

Jenis tanah lokasi penelitian adalah Organosol atau gambut saprik-topogen dalam lingkungan river peat (gambut matang, pembentukannya dipengaruhi pasang surut air sungai, dalam lingkungan sepanjang sungai).

\section{B. Data yang dikumpulkan}

Penelitian ini menggunakan bahan berupa tunggak bekas tebangan HTI Acacia crassicarpa. Peralatan penelitian meliputi phi band, meteran $100 \mathrm{~m}$, tally sheet, parang, chain saw dan drum pembakaran arang.

\section{Metode Penelitian}

\section{Penentuan Potensi Tunggak}

Penentuan potensi tunggak dilakukan dengan pengambilan sampel di areal tebangan secara sistematik dengan awal acak. Pengambilan sampel dilakukan pada plot berukuran $23,36 \times 23,36 \mathrm{~m}$ (0,05 ha) (Simon, 1996) dengan 3 (tiga) kali ulangan pada 2 lokasi tebangan, jarak antar plot adalah 50 meter dari batas luar plot. 


\section{a. Potensi tunggak termanfaatkan}

- Pembuatan plot pengamatan.

- Setiap tunggak yang ditemukan pada masing-masing plot pengukuran diidentifikasi apakah tunggak tersebut merupakan tunggak yang sudah tercerabut secara alami atau mekanis dan mudah untuk dilakukan pembongkaran (cukup dengan menggunakan teknologi sederhana/peralatan tangan) atau tunggak yang tidak terganggu.

- Tunggak yang masuk kategori mudah dibongkar dilakukan pembongkaran, pembersihan, penumpukkan dan penimbangan tunggak.

- Parameter yang diukur adalah volume (staple meter), diameter tunggak (pangkal batang tempat pemotongan tebangan dilakukan) dan berat tunggak.

\section{b. Potensi tunggak total}

- Pembuatan plot pengamatan.

- Semua tunggak yang ada pada plot pengamatan diukur diameternya (dgl), dicatat pada tally sheet.

Penentuan potensi tunggak untuk mengetahui rata-rata tunggak per luas tertentu dan total tunggak yang terdapat dalam satu distrik. Parameter yang menggambarkan potensi tunggak adalah volume ( $\mathrm{sm})$ dan berat $(\mathrm{kg})$.

\section{Analisa Biaya Pembuatan Arang Tunggak}

Analisa biaya dan kelayakan usaha pembuatan arang tunggak dilakukan untuk mendapatkan tingkat kelayakan usaha pembuatan arang tunggak $A$. crassicarpa. Unit analisis pengusahaan arang tunggak adalah skala kecil dan menengah. Data yang dikumpulkan adalah data biaya dari proses pemungutan tunggak, pengolahan tunggak, pembuatan dan pembakaran arang serta data harga arang kayu.

Analisa data biaya dan kelayakan pembuatan arang tunggak ini menggunakan analisa biaya manfaat untuk mendapatkan data kelayakan usaha pembuatan arang. Parameter kelayakan usaha adalah Net Present Value (NPV), Benefit Cost Ratio (BCR) dan Internal Rate of Return (IRR).

Dalam upaya mengkaji berbagai peluang ekonomis, penelitian ini melakukan analisis finansial pada 2 (dua) macam metode pembakaran, yaitu : pembakaran dengan lubang tanah dan pembakaran dengan drum. Pada masing-masing metode pembakaran dilakukan 2 (dua) macam simulasi randemen cacahan tunggak, yaitu 50\% dan $75 \%$.
Selanjutnya pada masing-masing metode pembakaran dan simulasi randemen diuji 6 skenario, yaitu :

1) semua biaya menjadi beban petani (full costing) dengan pemungutan tunggak dilakukan petani;

2) semua biaya menjadi beban petani (full costing) dengan pembelian tunggak dari perusahaan;

3) subsidi pemungutan tunggak, dikerjakan di luar petak tebangan;

4) subsidi pemungutan tunggak, dikerjakan di petak tebang;

5) subsidi pemungutan tunggak dan upah pembuatan arang, dikerjakan di luar petak tebang; dan

6) subsidi pemungutan tunggak dan upah pembuatan arang, dikerjakan di petak tebang.

\section{HASIL DAN PEMBAHASAN}

\section{A. Hasil}

\section{Potensi Tunggak}

Berdasarkan pengukuran pada petak ukur tidak permanen (PUTP) menunjukkan bahwa jumlah tunggak yang ditemukan berkisar antara 23 - 44 buah per plot, atau 460 - 880 buah per hektar. Jumlah tersebut memiliki variasi diameter berkisar antara 23-26,2 cm. Dengan demikian, total potensi tunggak per hektar dapat mencapai $222 \mathrm{sm}$ atau 15,8 ton (Tabel 1). Adapun tunggak yang potensial dapat dimanfaatkan dengan peralatan manual berkisar 100 - 200 buah tunggak per hektar dengan rata-rata volume sebesar 39,13 sm per hektar atau rata-rata bobot sekitar 3 ton per hektar (Tabel 2).

\section{Kelayakan Usaha Pengusahaan Arang Tunggak}

Analisis finansial memerlukan penetapan terlebih dahulu asumsi parameter teknis dan ekonomis sebagai landasar analisis (Tabel 3). Berdasarkan hasil kalkulasi menunjukkan bahwa sebagai sebuah investasi, pengusahaan arang tunggak masih perlu peningkatan efisiensi yang besar. Namun apabila subsidi diberikan pada tahapan pemungutan tunggak dan upah pembuatan arang menunjukkan status kelayakan usaha yang baik. Status kelayakan demikian berlaku pada metode pembakaran dengan drum maupun lubang tanah (Tabel 4 dan 5). 
Tabel(Table) 1. Total potensi tunggak hasil pengukuran dalam satuan volume dan berat (Total of stump potency based on measurement on volume and weight unit)

\begin{tabular}{|c|c|c|c|c|c|c|c|}
\hline \multirow[b]{2}{*}{$\begin{array}{l}\text { No. Plot } \\
\text { (No of } \\
\text { Plot) }\end{array}$} & \multirow{2}{*}{$\begin{array}{l}\text { Jml Tunggak } \\
\text { (buah)/ } \\
\text { Amount of } \\
\text { stump (unit) }\end{array}$} & \multicolumn{2}{|c|}{ Per Plot (Per Plot) } & \multicolumn{2}{|c|}{$\begin{array}{c}\text { Per Tunggak (Per } \\
\text { Stump) }\end{array}$} & \multicolumn{2}{|c|}{$\begin{array}{c}\text { Prediksi per ha } \\
\text { (Prediction per ha) }\end{array}$} \\
\hline & & $\begin{array}{l}\text { Volume } \\
(\mathrm{sm}) / \\
\text { Volume } \\
(\mathrm{sm})\end{array}$ & $\begin{array}{l}\text { Bobot }(\mathrm{kg}) / \\
\text { Weight }(\mathrm{kg})\end{array}$ & $\begin{array}{l}\text { Volume } \\
(\mathrm{sm}) / \\
\text { Volume } \\
(\mathrm{sm})\end{array}$ & $\begin{array}{c}\text { Bobot } \\
(\mathrm{kg}) / \\
\text { Weight } \\
(\mathrm{kg})\end{array}$ & $\begin{array}{l}\text { Volume } \\
(\mathrm{sm}) / \\
\text { Volume } \\
(\mathrm{sm})\end{array}$ & $\begin{array}{l}\text { Bobot }(\mathrm{kg}) / \\
\text { Weight (kg) }\end{array}$ \\
\hline 1 & 29 & 8,35 & 742,40 & 0,29 & 25,6 & 167,04 & 14.848 \\
\hline 2 & 35 & 12,75 & $1.368,50$ & 0,36 & 39,1 & 255,02 & 27.370 \\
\hline 3 & 44 & 26,27 & $1.108,80$ & 0,60 & 25,2 & 525,35 & 22.176 \\
\hline 4 & 23 & 3,59 & 427,80 & 0,16 & 18,6 & 71,73 & 8.556 \\
\hline 5 & 26 & 5,32 & 678,60 & 0,20 & 26,1 & 106,44 & 13.572 \\
\hline 6 & 23 & 10,34 & 423,20 & 0,45 & 18,4 & 206,83 & 8.464 \\
\hline Jumlah & 180.00 & 66,62 & $4.749,30$ & 2,06 & 153,00 & $1.332,41$ & $94.986,00$ \\
\hline Rerata & 30.00 & 11,10 & 791,55 & 0,34 & 25,50 & 222,07 & $15.831,00$ \\
\hline
\end{tabular}

Tabel (Table) 2. Potensi tunggak termanfaatkan dalam satuan volume dan berat (Potency of merchantable stump on volume and weight unit)

\begin{tabular}{|c|c|c|c|c|c|c|c|}
\hline \multirow[b]{2}{*}{$\begin{array}{l}\text { No. Plot } \\
\text { (No of } \\
\text { Plot) }\end{array}$} & \multirow{2}{*}{$\begin{array}{l}\text { Jml Tunggak } \\
\text { (buah)/ } \\
\text { Amount of } \\
\text { stump (unit) }\end{array}$} & \multicolumn{2}{|c|}{ Per Plot (Per Plot) } & \multicolumn{2}{|c|}{$\begin{array}{c}\text { Per Tunggak (Per } \\
\text { Stump) }\end{array}$} & \multicolumn{2}{|c|}{$\begin{array}{c}\text { Prediksi per ha } \\
\text { (Prediction per ha) }\end{array}$} \\
\hline & & $\begin{array}{c}\text { Volume } \\
(\mathrm{sm}) / \\
\text { Volume } \\
(\mathrm{sm}) \\
\end{array}$ & $\begin{array}{l}\text { Bobot (kg)/ } \\
\text { Weight (kg) }\end{array}$ & $\begin{array}{l}\text { Volume } \\
(\mathrm{sm}) / \\
\text { Volume } \\
(\mathrm{sm}) \\
\end{array}$ & $\begin{array}{c}\text { Bobot } \\
(\mathrm{kg}) / \\
\text { Weight } \\
(\mathrm{kg})\end{array}$ & $\begin{array}{l}\text { Volume } \\
(\mathrm{sm}) / \\
\text { Volume } \\
(\mathrm{sm}) \\
\end{array}$ & $\begin{array}{l}\text { Bobot }(\mathrm{kg}) / \\
\text { Weight }(\mathrm{kg})\end{array}$ \\
\hline 1 & 10 & 8,35 & 742,40 & 0,29 & 25,60 & 57,60 & $5.120,00$ \\
\hline 2 & 5 & 12,75 & $1.368,50$ & 0,36 & 39,10 & 36,43 & $3.910,00$ \\
\hline 3 & 5 & 26,27 & $1.108,80$ & 0,60 & 25,20 & 59,70 & $2.520,00$ \\
\hline 4 & 5 & 3,59 & 427,80 & 0,16 & 18,60 & 15,59 & $1.860,00$ \\
\hline 5 & 5 & 5,32 & 678,60 & 0,20 & 26,10 & 20,47 & $2.610,00$ \\
\hline 6 & 5 & 10,34 & 423,20 & 0,45 & 18,40 & 44,96 & $1.840,00$ \\
\hline Jumlah & 35.00 & 66,62 & $4.749,30$ & 2,06 & 153,00 & 234,76 & $17.860,00$ \\
\hline Rerata & 5.83 & 11,10 & 791,55 & 0,34 & 25,50 & 39,13 & $2.976,67$ \\
\hline
\end{tabular}

Tabel(Table) 3. Asumsi parameter teknis dan keuangan(Asumption of technical and finance parameter)

\begin{tabular}{|c|l|c|r|}
\hline $\begin{array}{c}\text { No. } \\
\text { (No.) }\end{array}$ & \multicolumn{1}{|c|}{$\begin{array}{c}\text { Asumsi Teknis } \\
\text { (Technical assumption) }\end{array}$} & $\begin{array}{c}\text { Satuan } \\
(\text { Unit })\end{array}$ & $\begin{array}{c}\text { Jumlah } \\
(\text { Total })\end{array}$ \\
\hline 1 & Periode produksi & & \\
\hline & a. Jam kerja sehari & Jam/hari & 8 \\
\hline & b. Hari kerja seminggu & Hari/minggu & 7 \\
\hline & c. Hari kerja sebulan & & 30 \\
\hline 2 & Proses produksi & Hari & 5 \\
\hline & a. Pembakaran \& pendinginan arang metode lubang tanah & Hari & 2 \\
\hline & b. Pembakaran dan pendinginan arang metode drum & $\mathrm{Kg} / \mathrm{bulan}$ & 1.000 \\
\hline & c. Kapasitas produksi arang & & \\
\hline 3 & Satuan dasar produksi & $\mathrm{Kg} / \mathrm{sm}$ & 50 \\
\hline & a. Randemen arang dari tunggak cacahan & $\%$ & 50 \\
\hline & b. Randemen tunggak cacahan dari tunggak bongkah & & \\
\hline
\end{tabular}


Tabel(Table) 3. Lanjutan(Continued)

\begin{tabular}{|c|l|c|c|}
\hline $\begin{array}{c}\text { No. } \\
(\text { No. })\end{array}$ & \multicolumn{1}{|c|}{$\begin{array}{c}\text { Asumsi Teknis } \\
\text { (Technical assumption })\end{array}$} & $\begin{array}{c}\text { Satuan } \\
(\text { Unit })\end{array}$ & $\begin{array}{c}\text { Jumlah } \\
(\text { Total })\end{array}$ \\
\hline 4 & Tenaga kerja produksi & & \\
\hline & a. Administrasi & OB & 0 \\
\hline & b. Pemotongan tunggak & HOK/ha & 2 \\
\hline & c. Penyaradan tunggak & HOK/ha & 2 \\
\hline & d. Sortasi dan pembersihan & HOK/sm & 0,2 \\
\hline & e. Pencacahan tunggak & HOK/sm & 0,25 \\
\hline & f. Pembakaran dan pendinginan metode lubang tanah & HOK/bulan & 30 \\
\hline & g. Pembakaran dan pendinginan metode drum & HOK & 30 \\
\hline & h. Pengepakan arang dari lubang tanah & HOK & 6 \\
\hline & i. Pengepakan arang dari drum & HOK & 15 \\
\hline 5 & Modal usaha & & \\
\hline & a. Asing & $\%$ & 0 \\
\hline & b. Sendiri & & 100 \\
\hline 6 & Pajak dan bunga & $\%$ & 0 \\
\hline & a. Pajak & $\% /$ tahun & 7 \\
\hline & b. Bunga & tahun & 0 \\
\hline & c. Lama pinjaman modal & Rp/kg & 1.000 \\
\hline 7 & Penjualan & & \\
\hline & $\quad$ Harga jual & Tahun & 5 \\
\hline 8 & Periode analisis & & \\
\hline & Waktu pengusahaan & & \\
\hline
\end{tabular}

Tabel(Table) 4. Resume analisis kelayakan usaha pembuatan arang tunggak A. crassicarpa (Resume of feasibility analysis on charcoal business made from stump of A. crassicarpa)

\begin{tabular}{|c|c|c|c|c|c|}
\hline \multirow{2}{*}{$\begin{array}{l}\text { No. } \\
(\text { No. })\end{array}$} & \multirow[t]{2}{*}{$\begin{array}{l}\text { Skenario pengusahaan } \\
\text { (Enterprising scenario) }\end{array}$} & \multicolumn{2}{|c|}{$\begin{array}{c}\text { Randemen cacahan } 50 \% \\
\text { (Randemen of stump chip 50\%) }\end{array}$} & \multicolumn{2}{|c|}{$\begin{array}{c}\text { Randemen cacahan } 75 \% \\
\text { (Randemen of stump chip } 75 \% \text { ) }\end{array}$} \\
\hline & & NPV (Rp) & $\mathrm{BCR}$ & $\mathrm{NPV}(\mathrm{Rp})$ & BCR \\
\hline $\begin{array}{l}\text { A. } \\
1\end{array}$ & $\begin{array}{l}\text { Pembakaran arang dengan lubang tanah } \\
\text { Full costing dengan pemungutan tunggak } \\
\text { oleh netani }\end{array}$ & $(238.836 .919,78)$ & 0,17 & $(195.511 .360,49)$ & 0,40 \\
\hline 2 & $\begin{array}{l}\text { Full costing dengan pembelian tunggak } \\
\text { dari perusahaan }\end{array}$ & $(447.126 .530,39)$ & 0,10 & $(334.453 .104,85)$ & 0,13 \\
\hline 3 & $\begin{array}{l}\text { Subsidi pemungutan tunggak, dikerjakan di } \\
\text { luar petak tebang }\end{array}$ & $(201.114 .684,23)$ & 0,30 & $(170.363 .203,46)$ & 0,30 \\
\hline 4 & $\begin{array}{l}\text { Subsidi pemungutan tunggak, dikerjakan di } \\
\text { petak tebang }\end{array}$ & $(201.114 .684,23)$ & 0,30 & $(170.363 .203,46)$ & 0,30 \\
\hline 5 & $\begin{array}{l}\text { Subsidi pemungutan tunggak \& pembuatan } \\
\text { arang, dikerjakan diluar petak tebang }\end{array}$ & $24.601 .184,62$ & 1,09 & $24.601 .184,62$ & 1,10 \\
\hline 6 & $\begin{array}{l}\text { Subsidi pemungutan tunggak \& pembuatan } \\
\text { arang, dikerjakan di petak tebang }\end{array}$ & $24.601 .184,62$ & 1,09 & $24.601 .184,62$ & 1,10 \\
\hline B. & Pembakaran arang dengan drum & & & & \\
\hline 1 & $\begin{array}{l}\text { Full costing dengan pemungutan tunggak } \\
\text { oleh petani }\end{array}$ & $(251.137 .512,09)$ & 0.16 & $(207.811 .952,80)$ & 0,19 \\
\hline 2 & $\begin{array}{l}\text { Full costing dengan pembelian tunggak } \\
\text { dari perusahaan }\end{array}$ & $(459.427 .122,70)$ & 0.10 & $(346.753 .697,16)$ & 0,12 \\
\hline 3 & $\begin{array}{l}\text { Subsidi pemungutan tunggak, dikerjakan di } \\
\text { luar petak tebang }\end{array}$ & $(213.415 .276,54)$ & 0.29 & $(182.663 .795,77)$ & 0,29 \\
\hline 4 & $\begin{array}{l}\text { Subsidi pemungutan tunggak, dikerjakan di } \\
\text { petak tebang }\end{array}$ & $(213.415 .276,54)$ & 0.29 & $(182.663 .795,77)$ & 0,29 \\
\hline 5 & $\begin{array}{l}\text { Subsidi pemungutan tunggak \& pembuatan } \\
\text { arang, dikerjakan diluar petak tebang }\end{array}$ & $17.220 .829,23$ & 1.06 & $17.220 .829,23$ & 1,07 \\
\hline 6 & $\begin{array}{l}\text { Subsidi pemungutan tunggak \& pembuatan } \\
\text { arang, dikerjakan di petak tebang }\end{array}$ & $17.220 .829,23$ & 1.06 & $17.220 .829,23$ & 1,07 \\
\hline
\end{tabular}




\section{B. Pembahasan}

\section{Potensi Tunggak}

Total potensi tunggak rata-rata di lokasi penelitian adalah 15,8 ton/ha atau $222 \mathrm{sm} / \mathrm{ha}$. Jika luas tebangan sesuai RKT 2009 adalah 1.150 ha dan RKT 2010 seluas 3.000 ha, maka total potensi tunggak yang tersedia pada tahun 2009 sebanyak 255.379,5 sm (atau 18.205,65 ton) dan pada tahun 2010 sebanyak 666.207,4 sm (atau 47.493 ton). Potensi tersebut sejalan dan dapat saling melengkapi dengan hasil temuan potensi kayu limbah hutan alam yang disitir Siregar (2005) dari hasil studi CIFOR di Malinau, Kalimantan Timur. Aktivitas pembalakan kayu di hutan alam menyisakan limbah kayu sebanyak $781 \mathrm{~m}^{3} / \mathrm{km}$ panjang jalan logging baru, yang terdiri dari $340 \mathrm{~m}^{3} / \mathrm{km}(51 \%)$ merupakan limbah kayu dari kategori batang tinggal, dan $141 \mathrm{~m}^{3} / \mathrm{km}(18 \%)$ merupakan limbah kayu dari kategori pohon mati tegak. Di lokasi pembukaan tempat pengumpulan kayu (TPn) dapat ditemukan setidaknya $207 \mathrm{~m}^{3} /$ ha limbah kayu, yang meliputi $101 \mathrm{~m}^{3}$ (49\%) merupakan limbah kayu dari kategori batang tinggal dan 43 $\mathrm{m}^{3}(21 \%)$ dari limbah kayu kategori pohon mati tegak.

Berdasarkan sumber yang sama, kegiatan pembukaan ladang baru oleh masyarakat pada kawasan hutan atau bekas ladang memiliki potensi limbah kayu sebesar $63 \mathrm{~m}^{3} / \mathrm{ha}$. Kategori limbah kayu yang dijumpai sebagian besar berupa sisa kayu sebesar $46 \mathrm{~m}^{3} / \mathrm{ha}(73 \%)$ dan tunggak sebesar $17 \mathrm{~m}^{3} /$ ha $(27 \%)$. Hasil inventarisasi potensi tunggak $A$. crassicarpa pada kawasan konsesi HTI pulp dapat dikomparasikan dengan pendekatan lain dalam estimasi potensi tunggak. Pendekatan tersebut menggunakan persamaan allomterik untuk menduga. Biomasa akar memiliki proporsi $20 \%$ dari total biomasa tanaman (Rahmat et al., 2007).

Berdasarkan hasil perhitungan biomasa A. crassicarpa umur 5 (lima) tahun oleh
Rochmayanto et al. (2009) pada areal HTI PT RAPP di Pelalawan, Riau menemukan biomasa akar yang relatif sama dengan hasil inventore pada penelitian ini. Biomasa akar yang dihitung secara alometris dan bobot tunggak yang di inventore secara sampling menghasilkan angka prediksi yang sama sebesar 15,8 ton/ha. Potensi tunggak yang dapat dimanfaatkan di lokasi penelitian adalah $39 \mathrm{sm} / \mathrm{ha}$ atau 3 ton/ha. Jumlah tersebut hanya sebesar $17,6 \%$ dari volume total dan 18,8\% dari bobot total per hektar. Proporsi tersebut berkaitan dengan tingkat kesulitan yang tinggi untuk melakukan pembongkaran tunggak secara manual. Konstruksi akar cukup dalam mencengkram tanah, dengan kedalaman 1,5 m dan radius $1 \mathrm{~m}$.

Pusat Litbang Hasil Hutan (2009) telah melakukan studi untuk menemukan angka konversi tunggak dari stapel meter adalah ke volume aktual, dari stapel meter ke berat dan dari volume aktual ke berat sebagaimana pada Tabel 5. Angka konversi tersebut dapat digunakan untuk menduga volume staple meter, volume aktual atau berat tunggak dari data dasar yang tersedia. Namun demikian, spesifikasi tunggak yang dihitung dalam staple meter adalah tunggak yang telah mengalami perlakuan pemotongan/ pembelahan dari bagian-bagian lain yang berpeluang menjadi limbah.

Angka konversi pada penelitian ini dapat dihitung dari hasil inventore dan nilainya berbeda karena perbedaan karakteristik tunggak yang menjadi obyek perhitungan. Konversi dari staple meter ke berat adalah $1 \mathrm{SM}=0,09$ ton, sedangkan konversi dari berat ke staple meter adalah 1 ton $=$ $14,15 \mathrm{SM}$.

\section{Analisis Finansial}

Dalam rangka implementasi pengembangan suatu proyek setelah dilakukan kajian teknis, lokasi dan lingkungan, maka penting terlebih dahulu dilakukan studi kelayakan guna memperoleh gambaran apakah suatu proyek layak dibangun dan memberi manfaat atau tidak

Tabel(Table)5. Angka konversi tunggak dari satuan staple meter ke volume aktual dan berat (Stump conversion factor from staple meter to actual volume and weight)

\begin{tabular}{|l|c|c|}
\hline \multicolumn{1}{|c|}{$\begin{array}{c}\text { Satuan awal } \\
\text { (Original unit })\end{array}$} & $\begin{array}{c}\text { Angka konversi ke satuan lain } \\
\text { (Confersion factor to other unit })\end{array}$ & $\begin{array}{c}\text { Kisaran } \\
\text { (Range) }\end{array}$ \\
\hline 1 stapel meter $(\mathrm{sm})$ & $0,3622 \mathrm{~m}^{3}$ & $0,3481-0,3763 \mathrm{~m}^{3}$ \\
\hline 1 stapel meter $(\mathrm{sm})$ & 0,3377 ton & $0,3333-0,3420$ ton \\
\hline $1 \mathrm{~m}^{3}$ & 0,9329 ton & $0,9209-0,9449$ ton \\
\hline
\end{tabular}


(Purba, 1996). Analisis kelayakan ini perlu juga sebagai alat pengambilan keputusan manajemen dalam pengelolaan sumber daya termasuk hutan (Fillius, 1992). Selain itu, pentingnya analisis ini juga diungkapkan oleh Gregersen and Contreras (1979) sebagai perangkat perencanaan dalam merespon pengembangan komoditas dan aktivitas di bidang kehutanan.

Studi yang dilakukan berbagai pihak dapat menunjukkan hasil yang berbeda sebab terdapat perbedaan parameter teknis dan keuangan yang digunakan. Oleh karena itu penting ditekankan pada analisis finansial ini asumsi parameter teknis dan ekonomi yang mendasari perhitungan pada studi ini sebagaimana pada Tabel 4. Skala pengusahaan adalah skala kecil atau industri rumah tangga, dengan kapasitas produksi arang adalah 1 ton per bulan dan tanpa menggunakan tenaga administrasi. Modal usaha seluruhnya berasal dari modal sendiri. Usaha ini tidak dikenai pajak karena tergolong sebagai industri kecil. Proses pembakaran dapat dipilih, apakah menggunakan lubang tanah atau drum. Tunggak yang digunakan adalah tunggak $A$. crassicarpa dari lokasi tebangan HTI pulp, dan masyarakat menggali sendiri tunggak sebagai bahan baku arang atas izin perusahaan.

Hasil analisis rugi laba pada semua skenario investasi (dengan memperhitungkan upah kerja) di kedua metode pembakaran menunjukkan situasi yang belum menguntungkan (Tabel 5). Hal ini menggambarkan bahwa masih terdapat sejumlah aktivitas yang perlu dilakukan efisiensi ekonomi secara ketat. Efisiensi ekonomi oleh Pearce and Stenzel (1972) didefinisikan sebagai suatu bentuk meminimalkan rata-rata total biaya produksi. Untuk meminimalkan rata-rata biaya total, input harus digunakan dalam kombinasi yang merefleksikan harga relatif dan produktivitas relatif. Skenario paling tidak efisien adalah apabila pembuatan arang dilakukan dengan pembakaran drum, tunggak membeli dari perusahaan dengan randemen cacahan $50 \%$. Kemampuan meningkatkan randemen menjadi 75\% merupakan upaya yang cukup baik karena mampu meningkatkan efisiensi $24,5 \%$. Apabila perusahaan mampu menyediakan tunggak siap angkut bagi masyarakat (ada subsidi pemungutan tunggak) dan masyarakat mengerjakan pembakaran arang dengan metode lubang tanah, maka efisiensi dapat ditingkatkan lagi menjadi $62,9 \%$.
Situasi pengusahaan arang yang paling layak (feasible) bagi petani adalah skenario pemberian subsidi pemungutan tunggak dan pembuatan arang. Situasi ini berlaku untuk metode pembakaran drum maupun lubang tanah pada randemen cacahan tunggak $50 \%$ maupun $75 \%$, pengerjaan di dalam maupun di luar petak tebangan. Pengusahaan pembuatan arang tunggak akan memberikan penghasilan bagi petani pada kisaran Rp 350.000,- sampai dengan Rp 500.000 ,- per bulan. Hasil kajian finansial ini dapat dibandingkan dengan laporan Nurhayati (2005) tentang pengusahaan arang dan cuka kayu, yang menggambarkan bahwa keuntungan memproduksi arang baru dapat diperoleh setelah tahun kelima produksi. Proporsi keuntungan terbesar dari kombinasi produk arang dan cuka kayu dipenuhi oleh cuka kayu yaitu 82,9\% per tahun. Dengan demikian sangat dibutuhkan keterpaduan manajemen pengusahaan pemanfaatan limbah tunggak dengan produk utamanya maupun produk turunan (misalnya cuka kayu dan arang aktif).

Kondisi teknologi pengambilan dan pengolahan tunggak yang ada saat ini, pengusahaan arang tunggak dapat layak bagi petani sebagai mata pencaharian tambahan. Pada skenario investasi diperoleh NPV $<0$, sedangkan dalam skenario subsidi NPV positif, dengan BCR 1,09 - 1,10 untuk metode pembakaran lubang tanah dan 1,06 - 1,07 untuk metode pembakaran drum. IRR diperoleh nilai yang sama untuk kedua metode pembakaran yaitu $55,04 \%$, sehingga usaha tani arang tunggak layak untuk dilakukan sepanjang inflasi (jika modal sendiri) atau bunga bank (jika modal berasal dari pinjaman bank) tidak melebihi 55,04\%.

Struktur biaya pengusahaan dalam skenario investasi dapat teridentifikasi beberapa komponen proses produksi yang perlu dilakukan efisiensi, yaitu :

\section{a. Proses pemungutan tunggak}

Pemungutan tunggak memerlukan waktu yang cukup lama karena terdiri dari aktivitasaktivitas yang berat jika dikerjakan secara manual. Proses pemungutan tunggak meliputi : penggalian, pencabutan, pemotongan bagian akar tunggang dan akar cabang, pembersihan tunggak dan penyaradan tunggak ke tempat pengumpulan. Untuk mengerjakan keseluruhan proses ini diperlukan waktu yang panjang atau jumlah tenaga kerja yang lebih banyak. 


\section{b. Pencacahan tunggak}

Pencacahan tunggak merupakan proses pemotongan dan atau pembelahan tunggak menjadi bagian/ukuran kecil sehingga tunggak dapat terbakar sampai ke bagian dalamnya. Proses ini memerlukan waktu lebih lama dan atau tenaga kerja yang sangat terampil sebab sifat fisik tunggak krasikarpa memiliki tingkat kekerasan yang tinggi.

Secara manual, pengumpulan dan pencacahan tunggak mengalami inefisiensi yang besar. Dengan demikian diperlukan suatu teknologi rekayasa alat pencacah tunggak, dan proses pemungutan tunggak perlu mendapat subsidi atau bantuan melalui penggunaan alat berat secara bersamaan dengan proses penebangan HTI.

\section{Implikasibagi Pengembangan Arang Tunggak}

Konsep efisiensi secara luas yang digunakan dalam ilmu ekonomi menjelaskan bahwa alokasi optimal sumber daya alam dan dikenalkan sebagai suatu tujuan ekonomis logis bagi individu, perusahaan maupun masyarakat. Dalam pengertian yang lebih sempit, efisiensi dinyatakan sebagai suatu upaya menghasilkan output yang maksimal atau meminimalkan limbah dari sumber daya yang terbatas (Carter and Siry, 2004).

Berangkat dari konsep tersebut, hasil penelitian ini diarahkan pada upaya membangun skenario optimis. Setiap keunggulan dari upaya pemanfaatan tunggak ini dipandang sebagai suatu peluang, dan setiap kendala dari upaya tersebut dipandang sebagai sebuah tantangan. Tantangan bukan aspek yang melemahkan tujuan, tapi aspek yang akan membangkitkan inovasi untuk mengantisipasi kendala dalam mencapai tujuan. Secara konseptual peluang dan tantangan pemanfaatan tunggak $A$. crassicarpa digambarkan pada skema di bawah ini.

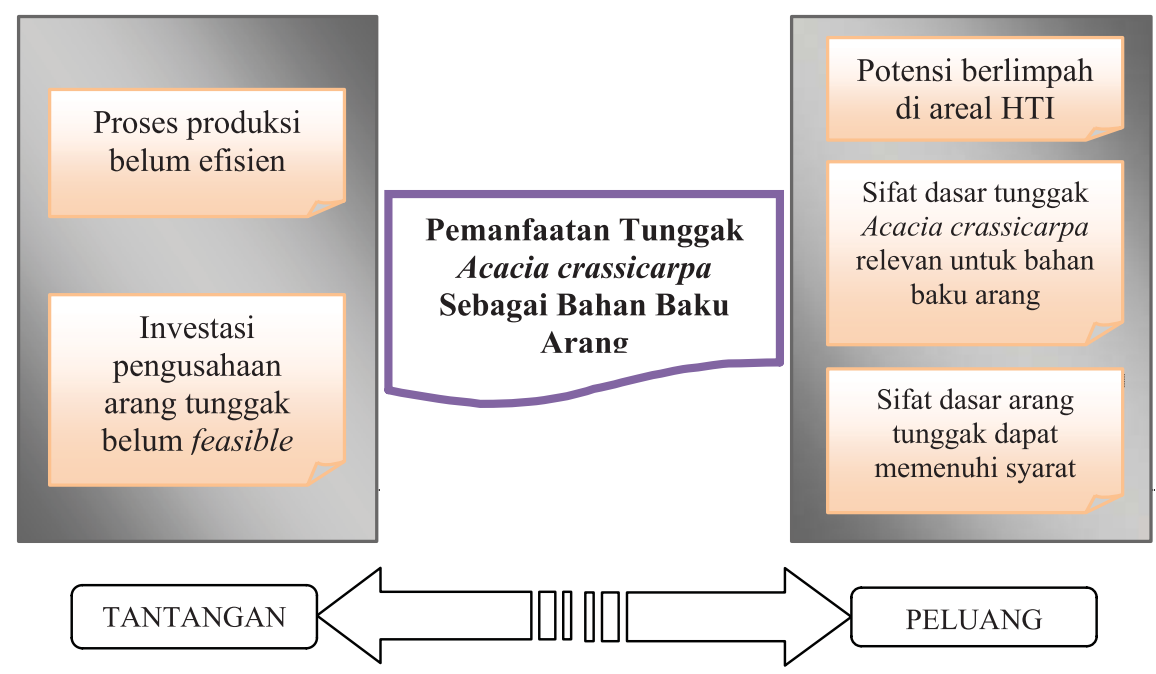

Gambar (Figure) 1. Peluang dan tantangan pemanfaatan tunggak A. crassicarpa (Opportunity and threat utilizing stump of A. crassicarpa)

Menghadapi situasi demikian, implikasi yang dapat dihadapi adalah :

1. Diperlukan teknologi rekayasa alat pencacah tunggak untuk meningkatkan randemen serta merasionalisasi jumlah tenaga kerja yang digunakan untuk menghasilkan randemen yang wajar.

2. Integrasi dan kemitraan dengan pengusaha HTI pulp diperlukan dalam rangka menghindari panjangnya rantai tata niaga bahan baku. Integrasi industri kayu pulp dengan arang, atau arang dengan produk turunannya (arang aktif dan cuka kayu) dapat meningkatkan efisiensi dan nilai tambah produk.

3. Memperhitungkan indirect positive effect, yaitu beberapa dampak baik kuantitas maupun kualitas barang/jasa dalam proyek yang dapat tersedia bagi masyarakat dalam proyek yang tidak termasuk dalam perhitungan analisis finansial, tidak secara langsung dibeli atau dijual dalam pasar.

Konsep indirect effect dikemukakan oleh Gregersen and Contreras (1979) sebagai 
pengaruh tidak langsung dari suatu proyek yang tidak bisa ternilai secara penuh dalam bentuk moneter, namun harus secara hati-hati dihitung karena positive indirect effect dapat berhubungan dengan negative indirect effect. Dengan demikian pengaruh yang diperhitungkan dalam analisis adalah net indirect effect.

Dalam rangka pembuatan arang tunggak, positive indirect effect yang perlu diperhitungkan antara lain serapan tenaga kerja, peningkatan nilai tambah kayu Acacia crassicarpa, dan mereduksi sumber penyakit di lahan penanaman. Sedangkan negative effect antara lain adalah terbentuknya cekungan dan menjadi sumber genangan air pada bekas cabutan tunggak serta menimbulkan polusi udara pada proses pembakaran arang. Apabila net indirect effect bernilai positif, berarti upaya pemanfaatan tunggak Acacia crassicarpa bermanfaat atau bernilai sosial positif.

\section{KESIMPULAN DAN SARAN}

\section{A. Kesimpulan}

1. Potensi total limbah pembalakan HTI di lahan gambut berupa tunggak kayu Acacia crassicarpa adalah 15,8 ton/ha atau 222 $\mathrm{sm} / \mathrm{ha}$. Sedangkan potensi tunggak termanfaatkan adalah 3 ton/ha atau $39 \mathrm{sm} / \mathrm{ha}$.

2. Pengusahaan arang tunggak belum layak sebagai sebuah investasi. Pengusahaan arang tunggak akan layak dilakukan oleh masyarakat dengan intervensi subsidi dari pemerintah atau perusahaan, atau sebagai mata pencaharian tambahan bagi petani. Skenario subsidi memberikan NPV sebesar Rp 17.220.829,23,- dan Rp 24.601.184,62,dengan BCR 1,09 dan 1,06 masing-masing untuk metode drum dan lubang tanah. IRR pada kedua metode adalah 55,04\%.

\section{B. Saran}

1. Petani dapat memanfaatkan tunggak sisa tebangan HTI pulp untuk dijadikan arang. Metode paling ekonomis bagi petani adalah dengan menggunakan cara pembakaran lubang tanah.

2. Tunggak kayu $A$. crassicarpa yang dijadikan sebagai bahan baku arang dapat berasal dari lahan gambut maupun mineral. Jika berasal dari lahan gambut, pengambilan tunggak lebih baik difokuskan pada tunggak yang telah tercerabut secara alami agar tidak merusak konstruksi lahan dan meninggalkan cekungan.
3. Integrasi dan kemiteraan dengan pengusaha HTI pulp diperlukan dalam rangka menghindari panjangnya rantai tata niaga bahan baku.

4. Perlu melakukan kalkulasi dampak positif tidak langsung dari pemanfaatan tunggak. Jika benefit sosial dan lingkungannya lebih tinggi dari biayanya, maka pemanfaatan tunggak layak diteruskan.

\section{DAFTAR PUSTAKA}

Bank Indonesia. 2009. Pola Pembiayaan Usaha Kecil (PPUK), Pengolahan Arang Tempurung. Bank Indonesia, Direktorat Kredit, BPR dan UMKM. Jakarta.

Carter, D.R. and J.P. Siry. 2004. Forest in Market Economy. Kluwer Academic Publisher. Netherland.

Departemen Kehutanan. 2007. Statistik Kehutanan Indonesia. Departemen Kehutanan RI. http://www.dephut.go.id/files/Stat 2007. pdf. [14 Maret 2008].

Departemen Kehutanan. 2008. Eksekutif Data Strategis Kehutanan 2008. Departemen Kehutanan RI. Jakarta.

Fillius, A.M. 1992. Invesment Analysis in Forest Management, Principal and Applications. Agricultural University, Departement of Forestry. Wageningen.

Gregersen H. M. and A.H. Contreras. 1979. Economics Analysis of Forestry Projects. Food and Agriculture Organization of The United Nations. Rome.

Nurhayati, T. 2005. Pengembangan Usaha Mikro, Kecil dan Menengah Produk Terpadu Arang dan Cuka Kayu. Semiloka Promosi Gaharu, Pengolahan Arang dan Cuka Kayu serta Mikoriza. Pekanbaru, 24 Agustus 2005. Biro Kerjasama Luar Negeri, Departemen Kehutanan.

Pearce, J. K. and G. Stenzel. 1972. Logging and Pulpwood Production. The Ronald Press Company. New York.

Purba, R. 1996. Analisis Biaya dan Manfaat. Rineka Cipta. Jakarta.

Pusat Litbang Hasil Hutan. 2009. Laporan Studi Penetapan Angka Konversi Tunggak Acacia mangium dan Acacia crassicarpa di Hutan Tanaman Industri PT Arara Abadi 
Provinsi Riau. Pusat Penelitian dan Pengembangan Hasil Hutan bekerja sama dengan Direktorat Bina Iuran Kehutanan dan Peredaran Hasil Hutan. Departemen Kehutanan. Jakarta.

Rahmat M., A. Sumadi, dan A.B. Hidayat. 2007a. Pendugaan Serapan Karbon Hutan Tanaman Acacia crassicarpa pada Lahan Gambut. Laporan Hasil Penelitian Balai Penelitian Kehutanan Palembang.

Rimbawanto, A. 2007. Peran Pemuliaan Pohon dalam Pengembangan HTI Pulp. Makalah disampaikan pada Sosialisasi Kegiatan BPHPS Guna Mendukung Kebutuhan Riset Hutan Tanaman Kayu Pulp di Pekanbaru pada tanggal 27 November 2007. Pekanbaru: Balai Penelitian Hutan Penghasil Serat.

Rochmayanto, Y., Sudarmalik, E. Novriyanti, Y. Aprianis. dan A. Pribadi. 2009. Pemanfaatan Tunggak Acacia crassicarpa Sebagai Bahan Baku Arang. Laporan Hasil Penelitian. Balai Penelitian Hutan Penghasil Serat Kuok.
Rostiwati T, Y. Heryati, dan S. Bustomi. 2006. Review Hasil Penelitian Kayu Energi dan Turunannya. Pusat Penelitian dan Pengembangan Hutan Tanaman. Bogor.

Setiawan, I., T. R. Syahputra, A. Pratama, dan D. Irawan. 2000. Usaha Gudang Arang. http://www.bloger.com. Diakses 15 februari 2010.

Simon, H. 1996. Metode Inventore Hutan. Aditya Media. Yogyakarta.

Siregar, C.A. 2005. Penerapan Sistem Tebang dan Arang (Slash and Char) - Alternatif Sistem Perladangan Berpindah. Dalam Iskandar, H. dan K.D Santosa. 2005. Cara Pembuatan Arang kayu, Altenatif Pemanfaatan Limbah Kayu Oleh Masyarakat. Center for International Forestry Research. Bogor.

Subandiyono. 2003. Prospek Usaha Pembuatan Arang Tempurung Kelapa (Studi Kasus UD Beringin Jaya. Tesis. Sekolah Pascasarjana. Institut Pertanian Bogor. Bogor. 